\title{
The use of deuterium oxide space to determine the amount of body fat in pregnant Blackface ewes
}

\author{
By JANET Z. FOOT* AND J. F. D. GREENHALGH \\ Rowett Research Institute, Bucksburn, Aberdeen $A B 2{ }_{9} S B$ \\ (Received 2 February 1970-Accepted 6 March 1970)
}

\begin{abstract}
I. The use of deuterium oxide dilution to obtain an indirect estimate of body water in pregnant ewes was examined and the value of such an estimate in predicting body fat was investigated.

2. Deuterium oxide was infused intravenously into fourteen twin-bearing Blackface ewes and blood samples were taken 6-7 h later. The animals were subsequently slaughtered.

3. Deuterium oxide concentration was estimated by infrared spectroscopy and the deuterium oxide space was calculated. Studies on dose rates and equilibration times were made with the Blackface ewes and some non-pregnant Dorset ewes.

4. The amount of body fat in each ewe was estimated from the deuterium oxide space using a prediction equation relating body fat to body water in twenty-five pregnant and non-pregnant ewes which had been slaughtered.

5. Once satisfactory measurement of deuterium oxide concentration had been achieved, body fat predicted from deuterium oxide space differed from values obtained by analysis of the slaughtered animals by -0.8 to $+1.7 \mathrm{~kg}$ in seven ewes containing $5.2-21.4 \mathrm{~kg}$ fat.

6. The standard deviation from regression of percentage of body fat estimated from deuterium oxide space on percentage of body fat measured after slaughter was $\pm \mathbf{r} \cdot \mathbf{2}$ percentage units. Thus deuterium oxide space was used to provide a useful measure of body fat in pregnant ewes.
\end{abstract}

In order to study the changes taking place in the body composition of pregnant ewes, we required a routine indirect method for making serial measurements of total body fat. Body fat can be estimated as the difference between total body-weight and lean body mass, and lean body mass can be predicted from measurements of body water. Relationships between total body water and lean body mass may be complicated in ruminants by the large proportion of body water held in the alimentary tract, and in pregnant animals by the proportion held in the uterus (Flanagan, I964). Reid, Bensadoun, Bull, Burton, Gleeson, Han, Joo, Johnson, McManus, Paladines, Stroud, Tyrrell, VanNiekerk, Wellington \& Wood (1968), who studied interrelationships between body components in 330 sheep and $25^{6}$ cattle, expressed their results in terms of empty (i.e. digesta-free) body-weight, but Panaretto (I963) found that total bodyweight and total body water were as satisfactory as the empty body values for predicting body fat in sheep and goats. With regard to the effect of pregnancy, we showed earlier (Foot, I969) that relationships between the water and fat contents of the body were substantially the same in pregnant and non-pregnant ewes. It appeared, therefore, that if body water could be estimated, it would be feasible to predict body fat in pregnant animals.

Of the marker substances used in the indirect estimation of body water, hydrogen isotopes appear the most promising since water containing these isotopes is not, in the

* Present address: Hill Farming Research Organization, 29 Lauder Road, Edinburgh EH 92 JQ. 
dilute solutions injected, affected selectively by any of the body's secretory or metabolic processes. Tritiated water has been used successfully to estimate body water in sheep and goats (Panaretto, 1963, 1964; Panaretto \& Till, 1963) and in cattle (Carnegie $\&$ Tulloh, 1968). As tritium is radioactive, the disposal of urine, faeces and carcasses from animals receiving it presents difficulties which may make its routine use unpractical. We therefore preferred the non-radioactive isotope, deuterium. In the work described in this paper we examined the value of deuterium oxide space in pregnant ewes as predictor of their total body water, and hence of their body fat.

\section{MATERIALS AND METHODS}

\section{Animals}

Fourteen pregnant Blackface ewes were infused with deuterium oxide. A description of the sheep is given in Table $I$; they were all the twin-bearing ewes in a group of twenty-five which were slaughtered in order to examine the relationship between body fat and body water in pregnant and non-pregnant sheep (Foot, 1969). Ewes in groups $I$ and 2 were slaughtered in 1967 and those in group 3 the following year.

In addition to the Blackface sheep, three Dorset ewes were infused with deuterium oxide in order to study the rate of equilibration. Two of these animals were nonpregnant and one in the rorst day of pregnancy. None of the Dorset ewes wasslaughtered.

Table r. Description of Blackface ewes infused with deuterium oxide

$\begin{array}{cccc}\text { Group } & \begin{array}{c}\text { No. of } \\ \text { ewes }\end{array} & \begin{array}{c}\text { Age } \\ \text { (years) }\end{array} & \begin{array}{c}\text { Days of } \\ \text { gestation }\end{array} \\ \mathbf{1} & 3 & 2 \cdot 5-3 & 93-98 \\ 2 & 6 & 3 & 14^{1-143} \\ 3 a & 3 & 4 & 141-143 \\ 3 b & 2 & 5 & 14 \mathbf{I}^{-143}\end{array}$

\section{Management of animals}

The sheep were kept in individual pens in a sheep-house; they were bedded on sawdust and had free access to drinking water. All ewes were being offered dried grass ad lib. at the time of infusion and slaughter, apart from two of the three ewes slaughtered at $93-98 \mathrm{~d}$ of gestation, one of these received hay $a d l i b$. and the other a restricted ration of hay and dried grass. Food and water were freely available right up to the time of slaughter.

\section{Infusion of deuterium oxide}

Deuterium oxide was infused in the form of $0.9 \%$ saline into the catheterized jugular vein from a $100 \mathrm{ml}$ all-glass syringe. The catheter consisted of about $75 \mathrm{~cm}$ of I. $19 \mathrm{~mm}$ bore flexible tubing with a small-bore hypodermic needle inserted in the outer end. Before the vein was catheterized the tubing was filled with physiological saline and after catheterization a small amount of saline was infused to make sure that the catheter was patent. The syringe containing deuterium oxide saline was locked to the needle in the catheter and its contents were infused steadily over an interval of a few minutes. The $100 \mathrm{ml}$ syringe was weighed before and after this infusion and the 
weight of deuterium oxide infused was calculated by difference. The catheter was flushed once more with physiological saline before being withdrawn. The original intention had been to estimate deuterium oxide concentration with a falling drop apparatus (Schloerb, Friis-Hansen, Edelman, Sheldon \& Moore, I95I) and at first the animals were infused with $40-50 \mathrm{~g}$ deuterium oxide $(0.65-0.87 \mathrm{~g} / \mathrm{kg}$ live weight). Later, when infrared spectroscopy proved a better method, it was found that more satisfactory results were obtained if more than $\mathrm{I} / \mathrm{kg}$ live weight was given.

\section{Sampling}

When the slaughter experiment began no figures were available from the equilibration studies, so it was assumed that equilibration times for deuterium oxide would be the same as for tritiated water (Till \& Downes, 1962). Samples of blood were withdrawn from the sheep before the infusion of deuterium oxide (blank sample) and either 4,5 and 6 or 5,6 and $7 \mathrm{~h}$ afterwards. In the equilibration studies, samples were withdrawn at various time intervals from $\mathrm{r} \cdot 5$ to $96 \mathrm{~h}$ after infusion. The samples were taken into $10 \mathrm{ml}$ non-heparinized evacuated tubes from the jugular vein opposite to that which had been catheterized. The serum was separated and stored at $-20^{\circ}$.

\section{Slaughtering procedure}

The ewes were slaughtered as soon as possible after the last blood sample had been taken. They were shorn just before slaughter and were weighed after shearing. If there was any delay between shearing and slaughter the sheep were weighed again just before slaughter. They were killed by exsanguination after anaesthesia or stunning. During the dissection procedure, which was described in an earlier paper (Foot, 1969), great care was taken to minimize evaporative losses. The moisture content of the whole body was determined by freeze-drying representative samples. Samples of fluids other than blood were also taken after slaughter to see if deuterium oxide was uniformly distributed in the body water. These samples included peritoneal fluid, amniotic and allantoic fluids, urine from the bladder and alimentary tract contents. All were stored at $-20^{\circ}$ to await distillation; samples of alimentary tract contents were centrifuged first and only the supernatant fraction was stored. All samples were sealed in glass tubes.

\section{Distillation of samples}

Most samples were subjected to heat distillation as described by Turner, Neely \& Hardy (rg6o). This method made use of standard laboratory glassware and was rapid, but it was not satisfactory for any samples of rumen contents and for some of small intestine contents. These samples were processed by the double vacuum-distillation method of Schloerb, Friis-Hansen, Edelman, Solomon \& Moore (1950).

Distilled samples were stored at $\mathrm{I}^{\circ}$ in sealed $\mathrm{I} 0 \mathrm{ml}$ glass containers.

\section{Estimation of deuterium oxide in samples}

The concentration of deuterium oxide in the water distilled from the samples was estimated by a differential absorption technique with an infrared spectrophotometer. 
Turner et al. (1960) had used this method to determine low concentrations of deuterium oxide (about $0.2 \%$ ) in the water distilled from biological fluids. The method depends on the measurement of the specific absorbance of deuterium oxide molecules. At the wave-length chosen for analysis $(4 \mu \mathrm{m})$ deuterium oxide has a distinct absorption band. This is somewhat obscured by absorption of atmospheric carbon dioxide, but with a differential absorption technique it is possible to use the absorption peak as a measure of deuterium oxide concentration.

Distilled water was used as a reference absorber. The two cells used for the estimation were made of stainless steel with barium fluoride windows. The sample cell was semi-permanent, the path length being determined by the thickness of the neoprene spacer between the windows. The reference cell had a variable path length, between 0 and $0.6 \mathrm{~mm}$, adjusted by a vernier screw.

The spectrophotometer available, a Unicam SP 200, differed from that used by Turner et al. (1960) and had not previously been used for routine determination of deuterium oxide concentration. Preliminary tests carried out by the makers some years earlier had indicated that the use of the instrument was feasible but that lack of energy might prove limiting. Most of the energy available at normal programme energy control setting (E) was found to be absorbed by the water in the cells.

Preliminary work was carried out to determine the best energy setting for the spectrophotometer, the optimum path length for the cell and the time to allow for temperature equilibrium in each new sample. Routine measurements were eventually made with the programme energy control set at ${ }_{4} \mathrm{E}$ and the fixed path length cell having a $0.25 \mathrm{~mm}$ spacer. Every time the sample cell was filled it was left in the light path for $3 \mathrm{~min}$ before scanning to allow the temperature of its contents to equilibrate with that of the spectrophotometer and reference cell. Every sample was scanned twice and had a standard and blank run on the same recording chart. High and low standards were read off with each alternate sample. The corrected absorbance for samples and standards was determined from the charts, and deuterium oxide concentration in the sample was calculated as follows:

$$
\text { Deuterium oxide concentration }(\mathrm{v} / \mathrm{v})=\frac{T A-L A}{H A-L A} \times(H C-L C)+L C \text {, }
$$

where $T A=$ test absorbance, $L A=$ absorbance of low standard, $H A=$ absorbance of high standard, $L C=$ concentration of low standard and $H C=$ concentration of high standard.

\section{Estimation of deuterium oxide space}

Deuterium oxide space was calculated as

$$
\frac{\text { Weight of deuterium oxide infused }}{\text { Concentration of deuterium oxide in body fluid }(\mathrm{w} / \mathrm{v})} \text {. }
$$

(The density of deuterium oxide was taken as $\mathrm{I} \cdot 1073 \mathrm{~g} / \mathrm{ml}$ in converting concentrations $\mathrm{v} / \mathrm{v}$ into concentrations $\mathrm{w} / \mathrm{v}$.)

The deuterium oxide space calculated for each sheep was compared with the value obtained for body water by desiccation. 


\section{Estimation of body fat}

Body fat was calculated by substituting deuterium oxide space for total body water in the following equation:

where

$$
\text { Weight of body fat }(\mathrm{kg})=0.892 \mathrm{~W}-\mathrm{I} \cdot 034 \mathrm{H}-2 \cdot 6 \text {, }
$$

$$
W=\text { total body-weight }(\mathrm{kg}) \text { and } H=\text { weight of total body water }(\mathrm{kg}) \text {. }
$$

This equation was derived from the relationship between body water (determined by desiccation) and body fat in the group of twenty-five pregnant and non-pregnant ewes which included those in this experiment. The estimates produced in this way were compared with values obtained by analysis of slaughtered sheep.

\section{RESULTS}

The estimates of deuterium oxide space in thirteen of the fourteen ewes are given in Table 2 together with the values for total body water determined by desiccation and the concentration of deuterium oxide in the samples. Deuterium oxide space was

Table 2. Body water estimated by desiccation and deuterium oxide space in pregnant

\begin{tabular}{|c|c|c|c|c|c|c|}
\hline \multirow[b]{2}{*}{ Group } & \multirow[b]{2}{*}{$\begin{array}{c}\text { Ewe } \\
\text { no. }\end{array}$} & \multirow{2}{*}{$\begin{array}{c}\text { Body } \\
\text { water by } \\
\text { desiccation } \\
\text { (l) }\end{array}$} & \multicolumn{2}{|c|}{ Deuterium oxide space } & \multicolumn{2}{|c|}{ Deuterium oxide $(\%, v / v)$ in: } \\
\hline & & & (1) & $\begin{array}{c}\% \text { body } \\
\text { water }\end{array}$ & 2nd sample* & 3rd samplet \\
\hline $\mathbf{I}$ & $\begin{array}{l}52 \\
55\end{array}$ & $\begin{array}{l}4 \mathrm{I} \cdot 0 \\
35 \cdot 3\end{array}$ & $\begin{array}{l}41 \% \\
354\end{array}$ & $\begin{array}{l}100 \cdot 0 \\
100.3\end{array}$ & $\frac{0.112}{-}$ & $\begin{array}{l}0.111 \\
0.120 f\end{array}$ \\
\hline 2 & $\begin{array}{l}32 \\
37 \\
38 \\
46 \\
48 \\
54\end{array}$ & $\begin{array}{l}57 \cdot 4 \\
53 \cdot 8 \\
45 \cdot 8 \\
49 \cdot 3 \\
46 \cdot 0 \\
46 \cdot 2\end{array}$ & $\begin{array}{l}65 \cdot 3 \\
56 \cdot 6 \\
48 \cdot 4 \\
50 \cdot 7 \\
48 \cdot 9 \\
47 \cdot 9\end{array}$ & $\begin{array}{l}\text { I } 3.8 \\
\text { I05.2 } \\
\text { I05.7 } \\
\text { I02.8 } \\
\text { I06.3 } \\
\text { 103.7 }\end{array}$ & $\begin{array}{l}0.066 \\
0.080 \\
0.099 \\
0.085 \\
0.097 \\
0.092\end{array}$ & $\begin{array}{l}0.070 \\
0.081 \\
0.096 \\
0.087 \\
0.088 \\
0.096\end{array}$ \\
\hline $3 a$ & $\begin{array}{l}29 \\
50 \\
53\end{array}$ & $\begin{array}{l}47 \cdot 9 \\
52 \cdot 4 \\
47 \cdot 5\end{array}$ & $\begin{array}{l}49 \cdot 3 \\
52 \cdot 3 \\
46 \cdot 9\end{array}$ & $\begin{array}{r}102 \cdot 9 \\
99 \cdot 8 \\
98 \cdot 7\end{array}$ & $\begin{array}{l}0.192 \\
0.181 \\
0.219\end{array}$ & $\begin{array}{l}0.204 \\
0.186 \\
0.221\end{array}$ \\
\hline $3 b$ & $\begin{array}{l}21 \\
26\end{array}$ & $\begin{array}{l}56 \cdot 7 \\
48 \cdot 5\end{array}$ & $\begin{array}{l}56 \cdot 5 \\
47 \cdot 4\end{array}$ & $\begin{array}{l}99 \cdot 6 \\
97 \cdot 7\end{array}$ & $\begin{array}{l}0.177 \\
0.175\end{array}$ & $\begin{array}{l}0.175 \\
0.2 \times 4\end{array}$ \\
\hline
\end{tabular}
Blackface ewes and concentrations of deuterium oxide in second and third serum samples

calculated from the concentration of deuterium oxide in the third serum sample, which had been taken either 6 or $7 \mathrm{~h}$ after infusion. It was, however, necessary to use the concentration of deuterium oxide in the amniotic fluid in one sheep (55) because the serum samples from this animal had been used up during early unsuccessful attempts to make the infrared spectrophotometric measurement.

Results from the third animal in the group infused at $93-98 \mathrm{~d}$ of pregnancy 
(group I) are not included in Table 2 because some deuterium oxide was lost during the infusion.

The apparent deuterium oxide space considerably overestimated body water in all the ewes infused near the end of pregnancy during the ist year of the experiment (group 2). The concentration of deuterium oxide in serum samples from these ewes was below $0.1 \%$ (Table 2 ).

Table 3. Body fat estimated from deuterium oxide space in Blackface ezwes

\begin{tabular}{|c|c|c|c|c|c|}
\hline \multirow[b]{2}{*}{$\begin{array}{c}\text { Ewe } \\
\text { no. }\end{array}$} & \multirow{2}{*}{$\begin{array}{l}\text { Live wt } \\
\text { (kg) }\end{array}$} & \multicolumn{2}{|c|}{ Wt of body fat $(\mathrm{kg})$} & \multicolumn{2}{|c|}{ Fat ( $\%$ of total body) } \\
\hline & & By analysis & Estimated* & By analysis & Estimated \\
\hline 52 & $56 \cdot 0$ & $5 \cdot 2$ & $5 \cdot 0(5 \cdot 0)$ & $9 \cdot 3$ & $8 \cdot 9$ \\
\hline 55 & $53 \cdot 8$ & $8 \cdot 4$ & $8 \cdot 8(8 \cdot 9)$ & 15.6 & $16 \cdot 4$ \\
\hline 29 & $75 \cdot 2$ & $14 \cdot 3$ & I $3.5(15.0)$ & 19.0 & 18.0 \\
\hline 50 & $87 \cdot 7$ & $2 \mathrm{I} \cdot 4$ & $2 I \cdot 5(2 I \cdot 4)$ & 243 & $24 \cdot 5$ \\
\hline 53 & $75 \cdot 1$ & $15 \cdot 0$ & I $5.9($ I $5 \cdot 3)$ & $20 \cdot 0$ & $2 I \cdot 2$ \\
\hline 21 & $90 \cdot 3$ & $20 \cdot 3$ & $19.5(19.3)$ & $22 \cdot 5$ & $2 x \cdot 6$ \\
\hline 26 & $80 \cdot 2$ & I $8 \cdot 2$ & $19.9(18.8)$ & 22.7 & $24 \cdot 8$ \\
\hline
\end{tabular}

* See p. 8r9; value estimated from deuterium oxide space and, in parentheses, estimated from water measured by desiccation.

Table 4. Percentage concentration of deuterium oxide $(v / v)$ in water distilled from various samples of body tissues and fuids from Blackface ewes

\begin{tabular}{|c|c|c|c|c|c|c|}
\hline Ewe no. $\quad \ldots \quad \ldots$ & 32 & 37 & $3^{8}$ & 46 & 48 & 54 \\
\hline Serum $\mathrm{x}$ & 0.063 & 0.079 & 0.103 & - & $0.08 \mathrm{I}$ & 0.092 \\
\hline Serum 2 & 0.066 & 0.080 & 0.099 & 0.085 & 0.097 & 0.092 \\
\hline Serum 3 & 0.070 & $0.08 I$ & 0.096 & 0.087 & 0.088 & 0.096 \\
\hline Contents of reticulo-rumen & 0.068 & - & 0.086 & - & 0.080 & - \\
\hline Contents of abomasum & 0.066 & 0.089 & 0.094 & 0.082 & 0.062 & 0.099 \\
\hline Contents of small intestine & 0.075 & 0.087 & 0.100 & - & $0.08 \mathrm{I}$ & 0.094 \\
\hline Mixed body fluids in body cavity & 0.077 & 0.073 & 0.097 & 0.084 & 0.062 & 0.096 \\
\hline Abdominal fluids & - & - & 0.099 & - & 0.090 & - \\
\hline Peritoneal fluids & - & 0.082 & - & - & 0.093 & 0.090 \\
\hline Urine & - & 0.075 & 0.095 & 一 & 0.094 & - \\
\hline Water distilled from carcass & - & - & - & 一 & - & 0.089 \\
\hline Allantoic fluid & 0.074 & 0.083 & 0.108 & 0.085 & 0.085 & 0.092 \\
\hline Amniotic fluid & 0.075 & 0.062 & 0.102 & 0.086 & 0.083 & 0.095 \\
\hline Foetal blood & 0.072 & 0.072 & 0.095 & $0.09 \mathrm{I}$ & 0.090 & - \\
\hline Mean (excepting serum samples $x, 2$ ) & 0.072 & 0.078 & 0.097 & 0.086 & 0.083 & 0.094 \\
\hline SE of mean & 0.0014 & 0.0028 & 0.0018 & 0.0012 & 0.0034 & 0.0012 \\
\hline
\end{tabular}

The weights of body fat estimated from deuterium oxide space in seven sheep are given in Table 3. The estimate was not made for any of the other six sheep, for which measurement of body water by deuterium oxide dilution was insufficiently accurate because of low concentrations of the marker. Also given in Table 3 are the determined values for ether-extractable fat in the same animals when slaughtered and the estimate of body fat from body water determined by desiccation. The estimates of body fat from deuterium oxide space differed from the determined values by -0.8 to $+\mathrm{I} \cdot 7 \mathrm{~kg}$ and the standard deviation from regression of the estimate on the determined value was $\pm 0.99 \mathrm{~kg}$; the standard deviation from regression of percentage of body 
fat estimated from deuterium oxide space on percentage of body fat measured after slaughter was $\pm I \cdot 2$ percentage units.

The percentage concentrations $(\mathrm{v} / \mathrm{v})$ of deuterium oxide in water from tissue and fluid samples from six sheep at slaughter are given in Table 4, together with the three values obtained from serum samples taken before slaughter. Mean values, with standard errors, are given for all measurements for each animal at slaughter (i.e. for all measurements excepting those for the first two serum samples). In the other ewes which were slaughtered sampling of body fluids was not so comprehensive.
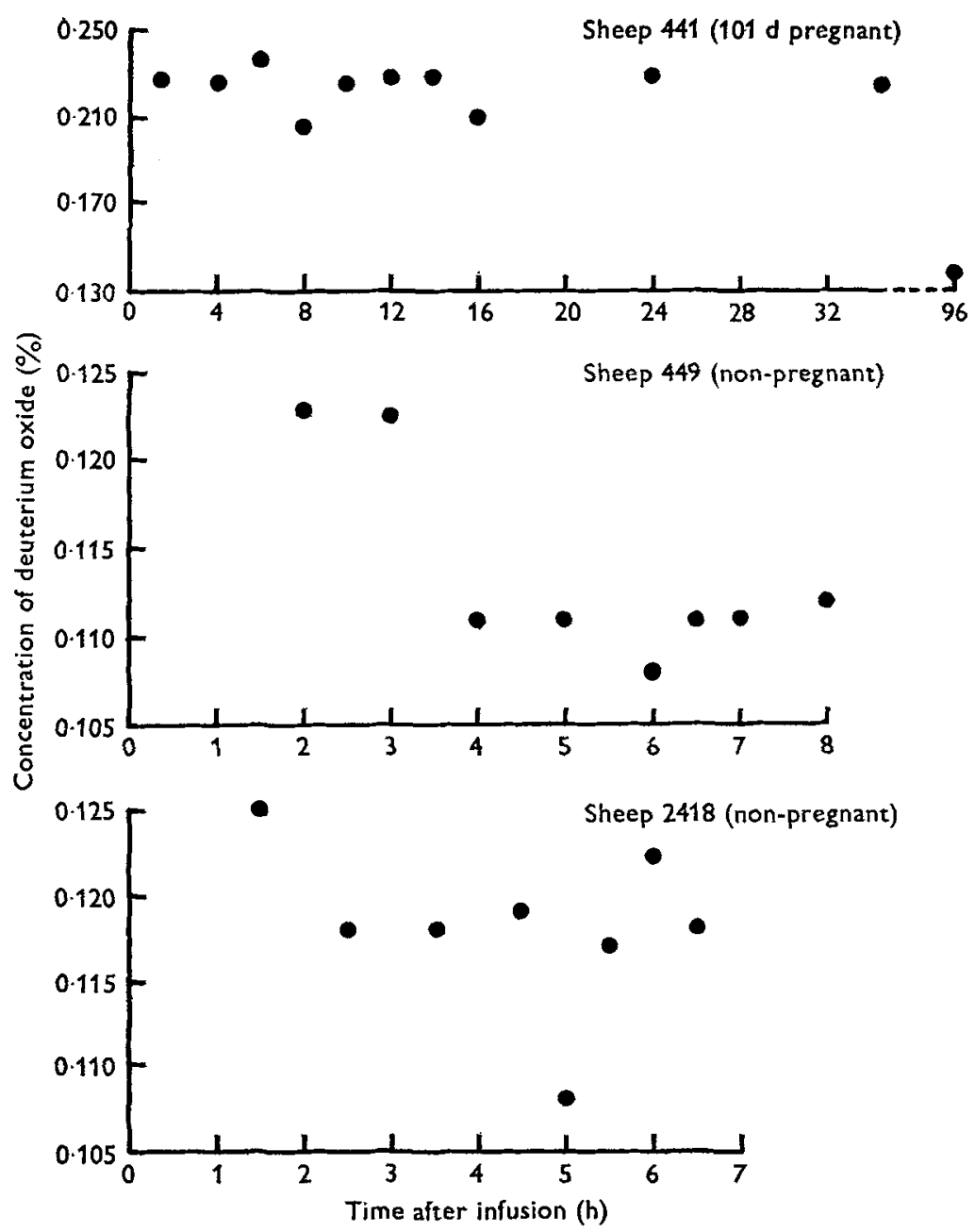

Fig. I. Percentage concentration of deuterium oxide in water distilled from serum samples taken serially after deuterium oxide infusion into Dorset ewes.

The results for serum samples taken serially from Dorset ewes are shown in Fig. I. Although there were some inconsistencies in the concentrations at certain times, it appeared that equilibration of deuterium oxide had been completed in the ewes by the end of the 6 or $7 \mathrm{~h}$ allowed to lapse after infusion. 


\section{DISCUSSION}

For deuterium oxide to be used successfully, its rate of distribution in the ruminant body had first to be known. As deuterium oxide and tritiated water have the same rates of distribution in rabbits (Anbar \& Lewitus, 1958), it was likely that this was so in sheep. It was therefore possible to obtain some guidance on equilibration time (about $6 \mathrm{~h}$ ) from work with tritiated water in sheep (Till \& Downes, 1962). In the present experiment, apart from a few exceptions discussed below, deuterium oxide concentrations in the last two of the serial serum samples were similar (Table 2) and deuterium oxide was evenly distributed in the various fluid samples from slaughtered sheep. It was unfortunate that the latter studies were carried out on the ewes which had been infused with the smallest dose of deuterium oxide. Nevertheless, these studies and those with non-pregnant sheep did lend support to the assumption that the time that should be allowed for equilibration of deuterium oxide was the same as that allowed for tritiated water.

On the other hand, there was no information available from other work with sheep on the amount of deuterium oxide which had to be infused to give satisfactory results. It was not even known how much water was likely to be present in the body of a pregnant ewe. The aim in the Ist year was to obtain a concentration of deuterium oxide in the body fluids of over $0.1 \%$, this being approximately the level used by Hytten, Taggart, Billewicz \& Jason (I962) in their work on pregnant women. They used the falling drop apparatus to estimate deuterium oxide, but we preferred the infrared spectrophotometer because we found the falling drop apparatus to be difficult to maintain and use on a routine basis. The main problem was maintenance of a sufficiently uniform environmental temperature for the column; the sensitivity was so great that there were rapid fluctuations in dropping times even under the most stable conditions we were able to achieve. The infrared spectrophotometer gave more reproducible results but its lower threshold of sensitivity was higher than that of the falling drop apparatus. It was eventually found that samples containing less than $0.1 \%$ deuterium oxide could not be relied upon to give clearly defined peaks on the recording chart. Reading of charts became increasingly difficult as the concentration of deuterium oxide declined below $0.1 \%$. In the ewes of group 2 , the concentrations of deuterium oxide were below $0.1 \%$, and this was probably the cause of the poor estimates of body water in all the ewes in this group; satisfactory results were obtained from the two sheep in group $\mathrm{I}$ where deuterium oxide concentrations were over $0.1 \%$. In addition, the samples from sheep in group 2 were the first read; at that time the techniques of using the spectrophotometer were still being modified and were presenting some problems, particularly with regard to available energy.

In the 2nd year of the experiment the time allowed for deuterium oxide to equilibrate was increased by $\mathrm{I} h$; there was not, however, a consistent difference between a $6 \mathrm{~h}$ and a $7 \mathrm{~h}$ sample in most sheep. A more important change in technique was the infusion of greater amounts of deuterium oxide, at least $\mathrm{I} g / \mathrm{kg}$ live weight. As can be seen in Table 3 , this resulted in concentrations of deuterium oxide in samples from animals in group 3 which were at least twice as high as those for group 2. Deuterium 
oxide space in ewes in group 3 gave a far better measure of total body water than it had done in ewes from group 2 . The $95 \%$ confidence intervals $(2 \times \mathrm{SE})$ for the volume and percentage of total body water predicted from deuterium oxide space in the seven sheep in groups I and 3 were 3.81 and $2.0 \%$ respectively. The corresponding value for the percentage of total body water estimated from tritiated water space in sheep by Panaretto (1963) was $2 \cdot 7 \%$. In our experiment the two sheep which contributed most to the error were nos. 29 and 26 . In the former, body water was overestimated by $\mathrm{I} \cdot 4 \mathrm{l}$ and in the latter it was underestimated by $\mathrm{I} \cdot \mathrm{I} l$. These two sheep were also the only ones in which there was not good agreement between concentrations of deuterium oxide in the second and third serum samples (Table 2). It is difficult to understand why the concentration in the third serum sample should be higher than that in the second from these two sheep. With fed sheep the opposite might be expected because ingestion of food and water should, in theory, have a diluting effect and lead to a lower concentration of deuterium oxide and hence an overestimate of body water. Carnegie \& Tulloh (1968) came to the conclusion that, if animals were not deprived of food and water before tritiated water space was estimated, their total body water would be seriously overestimated. In their work with twenty-six steers, with food freely available up to the time of infusion, tritiated water space overestimated body water by an average of $15 \%$, even though food was withheld between infusion and sampling. Panaretto (1963) deprived his sheep of food and water for the $48 \mathrm{~h}$ preceding injection of tritiated water and during the sampling period. Our results might have been better had we withheld food and water, but the method was being developed for use in a situation where a measure of the intake of food offered ad lib. might be required. In such an instance a $48 \mathrm{~h}$ fast might upset measurement of voluntary food intake over an extended period.

A second effect of allowing the animals access to food and water during the equilibration period might be to increase the rate of loss of deuterium oxide because defaecation and urination would be greater in the fed than in the starved animal. Another source of loss during equilibration is through evaporation and exchange with atmospheric moisture during respiration. At high ambient temperatures this source of loss may be greater than the loss in faeces and urine. However, under the conditions of this experiment respiratory losses were unlikely to amount to more than $\mathrm{x} \%$ of the dose in $24 \mathrm{~h}$.

The loss of tritiated water during a $6 \mathrm{~h}$ period in the wethers used in the experiment by Till \& Downes (I962) was less than $2 \%$ of the dose. The effect of any loss would depend on the concentration of deuterium oxide in the fluid loss from the body relative to the concentration in the total body fluid. In our Blackface ewes no loss was immediately apparent.

Another possible source of error was the exchange between deuterium and nonaqueous hydrogen ions. Reid, Balch \& Glascock (1958) found that such an exchange resulted in an error of $0.5-2 \%$ in the estimation of body water from tritiated water space in rabbits.

Panaretto ( 1963 ) and Panaretto \& Till ( 1963 ) calculated total body water in starved sheep and goats by reducing tritiated water space by $3 \%$ of live weight to allow for all 
sources of loss during equilibration. No such correction appeared to be justified in our work, the results being similar to those of Panaretto (1963) without correction.

In six of the seven animals for which the indirect estimate of body water was used to predict body fat, the resulting figures were within $\mathrm{I} \mathrm{kg}$ of the determined value and the difference between the values obtained directly and indirectly amounted to no more than $6 \%$ of the determined value. In the seventh animal, sheep 26 , the main cause of the large difference $(\mathrm{r} \cdot 7 \mathrm{~kg}$ fat, $9.3 \%)$ was inaccurate measurement of body water. As mentioned previously, equilibration of deuterium oxide may not have been complete in this sheep.

The seven animals in which body fat was predicted from deuterium oxide space were included in the group of twenty-five pregnant and non-pregnant ewes which were slaughtered and analysed in order to devise the prediction equation (I) which had a residual standard deviation of $\pm 0.56 \mathrm{~kg}$ body fat. When the weight of body fat was related to the weight of body water and body-weight for just the seven animals the following equation was derived:

$$
\begin{gathered}
\text { Weight of body fat }(\mathrm{kg})=0.794 W-0.802 H-6.38, \\
\text { residual standard deviation }= \pm 0.45 .
\end{gathered}
$$

When total body water values were replaced by those for deuterium oxide space $(D)$ in the same animals, the resulting equation was:

$$
\begin{gathered}
\text { Weight of body fat }(\mathrm{kg})=0.72 \mathrm{I} W-0.66_{3} D-7.54, \\
\text { residual standard deviation }= \pm 0.62 .
\end{gathered}
$$

Thus the error was increased by the use of deuterium oxide space instead of body water, but a large part of this error was due to one animal (26). The multiple correlation coefficient was 0.998 for equation (2) and 0.996 for equation (3).

Estimates of body fat made routinely in live animals might be expected to deviate further from true values than the estimates in this experiment. This is because the former estimates would be based on a prediction equation to which the animals studied had made no contribution. On the other hand, the technique of measuring body water should improve as experience of the required dose rates and sampling methods increases.

The major objection to the use of deuterium oxide seems to be the high cost per animal infused (between 70 and 80 shillings for a $60 \mathrm{~kg}$ sheep). Nevertheless, if tritiated water cannot be used, the cost would appear to be justified in a situation where individual variation invalidates the use of small slaughter groups for comparisons between sheep, or where measurements of sequential changes of body fat in a pregnant sheep are required. The deuterium oxide dilution technique, as used in clinical research on pregnant women, appears then to have a potential value.

We wish to thank Mr G. W. Reid and Mr R. I. Smart for technical assistance. J. Z. F. is grateful for the award to her of the Sir Frederick Smith Fellowship by the Royal College of Veterinary Surgeons, London. 


\section{REFERENCES}

Anbar, M. \& Lewitus, Z. (1958). Nature, Lond. 181, 344.

Carnegie, A. B. \& Tulloh, N. M. (1968). Proc. Aust. Soc. Anim. Prod. 7, 308.

Flanagan, B. (1964). Clin. Sci. 27, 335.

Foot, J. Z. (1969). J. Reprod. Fert. Suppl. 9, p. 9.

Hytten, F. E., Taggart, N., Billewicz, W. Z. \& Jason, A. C. (I962). Physics Med. Biol. 6, 4I 5.

Panaretto, B. A. (1963). Aust. F. agric. Res. 14, 944.

Panaretto, B. A. (1964). Aust. F. agric. Res. 15, 771.

Panaretto, B. A. \& Till, A. R. (1963). Aust. $\mathscr{F}$. agric. Res. 14, 926.

Reid, J. T., Balch, C. C. \& Glascock, R. F. (1958). Br. F. Nutr. 12, 43.

Reid, J. T., Bensadoun, A., Bull, L. S., Burton, J. H., Gleeson, P. A., Han, I. K., Joo, Y. D., Johnson, D. E., McManus, W. R., Paladines, O. L., Stroud, J. W., Tyrrell, H. F., VanNiekerk, B. D. H., Wellington, G. H. \& Wood, J. D. (1968). Proc. Cornell Nutr. Conf. Feed Mfrs p. 18.

Schloerb, P. R., Friis-Hansen, B. J., Edelman, I. S., Sheldon, D. B. \& Moore, F. D. (195 I). F. Lab. clin. Med. 37, 653.

Schloerb, P. R., Friis-Hansen, B. J., Edelman, I. S., Solomon, A. K. \& Moore, F. D. (r950). F. clin. Invest. 29, 1296.

Till, A. R. \& Downes, A. M. (1962). Aust. F. agric. Res. 13, 335.

Turner, M. D., Neely, W. A. \& Hardy, J. D. (1960). F. appl. Physiol. 15, 309. 